\title{
MIR19B2 Gene
}

National Cancer Institute

\section{Source}

National Cancer Institute. MIR19B2 Gene. NCI Thesaurus. Code C80738.

This gene is involved in the regulation of gene expression and plays a role in the development of hepatocellular carcinoma and T-cell leukemia. 